\title{
Reduction of Cu(II) in Matrix-Assisted Laser Desorption/Ionization Mass Spectrometry
}

\author{
Juan Zhang, Vladimir Frankevich, Richard Knochenmuss, \\ Sebastian D. Friess, and Renato Zenobi \\ Department of Chemistry, Swiss Federal Institute of Technology (ETH), ETH-Hönggerberg, Zurich, Switzerland
}

\begin{abstract}
The mechanisms of the reduction of $\mathrm{Cu}(\mathrm{II})$ in matrix-assisted laser desorption/ionization mass spectrometry (MALDI) are studied. In MALDI mass spectra, ions cationized by copper mostly contain $\mathrm{Cu}(\mathrm{I})$ even if $\mathrm{Cu}(\mathrm{II})$ salts are added to the sample. It was found that $\mathrm{Cu}$ (II) was reduced to $\mathrm{Cu}(\mathrm{I})$ by gas-phase charge exchange with matrix molecules, which is a thermodynamically favorable process. Under some conditions, large amounts of free electrons are present in the plume. $\mathrm{Cu}(\mathrm{II})$ can be even more efficiently reduced to $\mathrm{Cu}(\mathrm{I})$ by free electron capture in the gas phase. The matrices studied in this work are nicotinic acid, dithranol, and 2,5-dihydroxybenzoic acid. (J Am Soc Mass Spectrom 2003, 14, 42-50) () 2003 American Society for Mass Spectrometry
\end{abstract}

$\mathrm{T}$ The ionization process in matrix-assisted laser desorption/ionization mass spectrometry (MALDI MS) is still not fully understood, although this analytical method has become one of the most important tools for the analysis of biomolecules and polymers [1-10]. One of the noticeable MALDI phenomena is the dominance of singly charged ions. For instance, the adducts of multivalent metal ions are detected as singly charged quasimolecular ions formed either by deprotonation $\left([\mathrm{M}+\mathrm{Me}(\mathrm{II})-\mathrm{H}]^{+}\right)$or by reduction of metal ions $\left([\mathrm{M}+\mathrm{Me}(\mathrm{I})]^{+}\right)$, e.g., $\mathrm{Cu}(\mathrm{II})$ to $\mathrm{Cu}(\mathrm{I})$ [11-19]. Signals of both types of metal ion adducts $\left([\mathrm{M}+\mathrm{Me}(\mathrm{II})-\mathrm{H}]^{+}\right.$ and $[\mathrm{M}+\mathrm{Me}(\mathrm{I})]^{+}$) were observed in the analysis of proteins [11, 17, 19, 20] and polar synthetic polymers, e.g., polyethylene glycols (PEG) [12], whereas in the analysis of apolar synthetic polymers, e.g., polystyrene (PS), the reduction of divalent metal ions was dominant [13-16, 18].

In this work, we present a detailed study of the reduction of divalent copper used as a cationization agent in MALDI. Different explanations of this reduction in the gas phase have been given, namely electron capture [21] and charge exchange with matrix [22]. The origin and the amount of free electrons in MALDI has not been comprehensively investigated before and many questions were still open [22]. Recently, studies of the origin of the free electrons in MALDI from our laboratory [23, 24] have shown that free electrons are largely formed by photoelectric emission from a metal/ dielectric-substance interface, not by photoionization of

Published online November 28, 2002

Address reprint requests to Dr. R. Zenobi, Department of Chemistry, Swiss Federal Institute of Technology (ETH), ETH-Hönggerberg, HCI E 329, CH-8093 Zurich, Switzerland. E-mail: zenobi@org.chem.ethz.ch matrix [21]. Our studies also showed that the yield of electrons strongly depends on the thickness of the matrix layer. In the case of nonmetallic surfaces, few electrons are produced.

According to these results, we are able to investigate the roles of free electrons and matrices as possible reducing agents in MALDI separately. Blocking the electron source by using a nonmetallic sample carrier or a metallic target covered with an insulating layer provides the possibility to examine the effect of the gasphase charge transfer between divalent metal ions and the matrices. For investigation of the effect of the free electron capture, experiments have to be done in the absence of matrix by using direct laser desorption/ ionization (LDI) of the sample.

Under continuous extraction conditions, for example on a time-of-flight (TOF) mass spectrometer, free electrons as the most mobile species can either be extracted very quickly (in the negative ion mode) or pushed back towards the target (in the positive ion mode) and thus have less overlap with the plume, i.e., electrons will be less available for capture by positively charged species. On the other hand, delayed extraction allows time for secondary ion-molecule reactions to occur, e.g., the charge transfer reaction between neutral matrix molecules and copper ions. In order to investigate the influence of the high extraction field on the free electron capture and the charge exchange reaction, we have compared the results obtained under both the field free conditions (on a Fourier transform ion cyclotron resonance mass spectrometer (FT ICR MS) with internal MALDI source, or with delayed extraction on TOF MS) and with continuous extraction mode on a TOF MS. 


\section{Experimental}

\section{Material}

Copper (II) chloride dihydrate was purchased from Siegfried Handel (Zofingen, Switzerland). Matrices, including 2,5-dihydroxybenzoic acid (DHB), nicotinic acid (NA), 1,8,9-Anthracenetriol (dithranol), and high purity solvents (99.99\% ethanol and $99.95 \%$ tetrahydrofuran) were obtained from Fluka (Buchs, Switzerland).

\section{Sample Preparation}

$\mathrm{CuCl}_{2}$ was dissolved in water or in tetrahydrofuran (THF), nicotinic acid and 2,5-dihydroxybenzoic acid in water/ethanol (1:1), and dithranol in THF. Matrix- $\mathrm{Cu}$ solutions were obtained by mixing the aqueous $\mathrm{CuCl}_{2}$ solution with nicotinic acid or 2,5-dihydroxybenzoic acid solution in molar ratio about 1:1, or a $\mathrm{CuCl}_{2} / \mathrm{THF}$ solution with a dithranol/THF solution, respectively.

"Thin layer" preparation. Aqueous $\mathrm{CuCl}_{2}$ solution or matrix-Cu solution (ca. $0.5 \mu l$ ) was dropped on a stainless steel target. The drop on the metal surface was spread by hand with a spatula, in order to avoid build-up of a thick crystal layer and subsequently allowed to dry at room temperature. This sample preparation was employed for both FT ICR and TOF experiments.

"Insulating layer" preparation. There are three possibilities for inhibition of free electrons in MALDI: (1) A relatively thick sample layer. The thickness can, however, hardly be controlled, and it is also sample-consuming. (2) An insulating layer on metallic target, e.g., an adhesive tape. (3) A nonmetallic target, which can only be used if there is no extraction field required. For the TOF MS experiments, adhesive tape was used as insulating layer. Pieces of adhesive tape with 1-2 mm diameter were stuck on the stainless steel target. The size of the tape piece was too small to have any effect on the shape of the extraction field. The sample solutions were dropped onto the tape and dried under room temperature. The thickness of the sample here is not important. For FT ICR experiments, special targets made from polyetheretherketone (PEEK) or from ceramic ( $3 \mathrm{~mm}$ thick of Macor, obtained from $\mathrm{E}$ and $\mathrm{P}$ Fiber Optic AG, Spreitenbach, Switzerland, fixed on top of the stainless steel target) were employed.

Direct laser desorption/ionization. For investigating the reduction of $\mathrm{Cu}(\mathrm{II})$ in the absence of matrix, direct laser desorption/ionization of the copper salt was employed on both the metallic and nonmetallic sample targets, or with an insulating tape on the metallic target in the TOF MS experiments.

\section{FT ICR MS}

A FT ICR MS with an open elongated cylindrical cell was employed [25]. The instrument is equipped with a 4.7 tesla superconducting magnet (Bruker, Fällanden, Switzerland) and Odyssey data acquisition electronics (Finnigan, Madison, WI). A Nd:YAG laser (Minilite ML-10, Continuum, CA) operated at $355 \mathrm{~nm}$ was employed for laser desorption. The sample target was placed right behind the cell at $2 \mathrm{~cm}$ distance. The variation of laser energy was controlled by the variation of the delay between flash lamp and Q-switch. After laser desorption, the ions were allowed to drift into the ICR cell, and were subsequently trapped by using gated trapping, excited, and detected. Experiments were carried out in both positive and negative ion mode, on both stainless steel and PEEK sample targets. The investigation of the laser pulse energy dependence was also accomplished on the FT ICR instrument.

\section{TOF MS}

Experiments were also performed on a commercial MALDI TOF MS (Axima CFR from Shimadzu/Kratos, Manchester UK). The total acceleration voltage was 20 $\mathrm{kV}$. For laser desorption, a nitrogen laser operated at $337 \mathrm{~nm}$ was employed. Experiments were performed in linear negative ion mode, with and without delayed extraction.

\section{Ab Initio Calculation}

Density functional theory (DFT) using combined Becke's three-parameter exchange functional and the gradient-corrected functional of Lee, Yang and Parr (B3LYP functional) [26-28] was employed in this work for the calculations of the ionization potentials at the $6-31+G^{*}$ level. The energy required to remove an electron is calculated as the energy difference between the neutral and the positively-charged radical species. Geometry optimization and frequency calculation were performed for both the neutral molecule and the cation. The Gaussian 98 package was used for all calculations [29].

\section{Results and Discussion}

\section{No Matrix, No Free Electrons}

Before studying the influence of free electrons and matrix on the reduction of $\mathrm{Cu}(\mathrm{II})$, we obtained spectra from $\mathrm{CuCl}_{2}$ in the absence of both free electrons and matrix. Figure 1 shows the FT ICR mass spectra of $\mathrm{CuCl}_{2}$ obtained by LDI directly from $\mathrm{CuCl}_{2}$ on the PEEK target. Figure $1 \mathrm{a}$ is a negative ion mode spectrum, whereas Figure $1 \mathrm{~b}$ shows the positive ions. Numerous $\mathrm{Cu}_{\mathrm{m}} \mathrm{Cl}_{\mathrm{n}}$ clusters with variable composition and $\mathrm{Cu}$ oxidation states were observed up to $m / z=700$.

All the signals representing $\mathrm{Cu}_{\mathrm{m}} \mathrm{Cl}_{\mathrm{n}}$ observed in the 

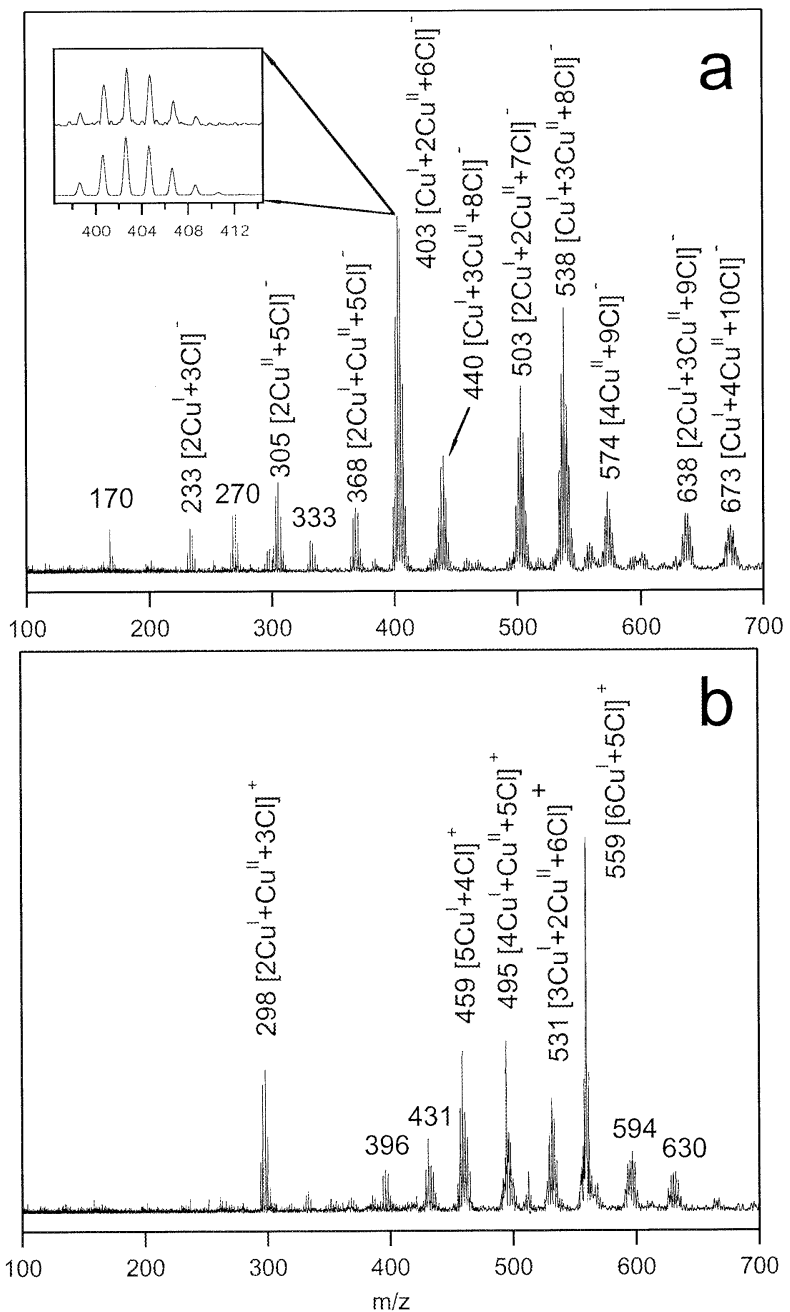

Figure 1. FT MS mass spectra of $\mathrm{CuCl}_{2}$ obtained on a PEEK target by direct laser desorption/ionization in the absence of matrix. (a) Negative ion mode, (b) positive ion mode. The signals were identified by comparing the isotope patterns of the measured signals with the calculated isotope distributions. Inset: Magnification of peak at $\mathrm{m} / \mathrm{z} 403$ (upper trace) and the calculated isotope distribution (lower trace).

positive and negative ion mode spectra in all the figures of this work are listed in Table 1. The signals were identified by their $\mathrm{m} / \mathrm{z}$ ratio and by comparing the measured isotope distribution (ID) pattern (Figure 1a inset: Upper trace) with the calculated ID pattern (lower trace). For example, we consider the signal at $\mathrm{m} / \mathrm{z} 403$ in the negative ion mode spectrum and compare its ID with the simulated ID of different $\mathrm{Cu}_{\mathrm{m}} \mathrm{Cl}_{\mathrm{n}}$ complexes. The signal at $\mathrm{m} / \mathrm{z} 403$ can thus be identified as $\left[\mathrm{Cu}_{3} \mathrm{Cl}_{6}\right]^{-}$. For this complex, there is only one possible combination of the oxidation states of copper, namely, $\left[\mathrm{Cu}^{\mathrm{I}}+2 \mathrm{Cu}^{\mathrm{II}}+6 \mathrm{Cl}\right]^{-}$. In cases where there is more than one combination, we took the one corresponding to the lower oxidation states ( 0 and I) of copper, because of the lability of $\mathrm{Cu}(\mathrm{II})$ in the presence of $\mathrm{Cu}(0)(\mathrm{Cu}(0)+\mathrm{Cu}(\mathrm{II})$ $\rightarrow 2 \mathrm{Cu}(\mathrm{I}),-13 \mathrm{eV})$. For example, $m / z 296$ in negative ion mode is $\left[\mathrm{Cu}_{3} \mathrm{Cl}_{3}\right]^{-}$, and the two combinations for this complex are: $\left[\mathrm{Cu}^{0}+2 \mathrm{Cu}^{\mathrm{I}}+3 \mathrm{Cl}\right]^{-}$and $\left[2 \mathrm{Cu}^{0}+\mathrm{Cu}^{\mathrm{II}}+\right.$
$3 \mathrm{Cl}]^{-}$. The latter one is not supposed to be likely because of the reason mentioned above. Thus, the signal at $m / z 296$ is identified as $\left[\mathrm{Cu}^{0}+2 \mathrm{Cu}^{\mathrm{I}}+3 \mathrm{Cl}\right]^{-}$.

Three oxidation states of copper, i.e., $\mathrm{Cu}(0), \mathrm{Cu}(\mathrm{I})$, and $\mathrm{Cu}(\mathrm{II})$, were observed, although we used only copper (II) chloride. The abundance of complexes containing $\mathrm{Cu}(0)$ was always very low. In the negative ion mode spectrum (Figure 1a), the intense signals mainly represent $\mathrm{Cu}(\mathrm{II})$. In positive ion mode, the signals mainly present $\mathrm{Cu}(\mathrm{I})$. A explanation for this might be that most $\mathrm{Cu}$ (II) containing $\mathrm{Cu}_{\mathrm{m}} \mathrm{Cl}_{\mathrm{n}}$ clusters can have more $\mathrm{Cl}^{-}$ions as ligands than $\mathrm{Cu}(\mathrm{I})$ containing clusters because of the high charge density of $\mathrm{Cu}(\mathrm{II})$, which leads to a negative net charge for most of $\mathrm{Cu}$ (II) containing $\mathrm{Cu}_{\mathrm{m}} \mathrm{Cl}_{\mathrm{n}}$ clusters, and a positive charge for most of $\mathrm{Cu}(\mathrm{I})$ containing clusters. The ratios of $\mathrm{Cu}(\mathrm{I}) /$ $\mathrm{Cu}$ (II) in the negative and positive ion mode mass spectra are 0.54 and 3.5, respectively, calculated by using eq 1 ,

$$
\frac{C u(I)}{C u(I I)}=\frac{\Sigma I_{k} \cdot N_{C u(I)}}{\Sigma I_{k} \cdot N_{C u(I I)}}
$$

where $I_{k}$ is the sum of the intensities of all the isotope signals in the $\mathrm{k}^{\text {th }}$ signal group, and $N_{C u(I)}$ and $N_{C u(I I)}$ are the numbers of $\mathrm{Cu}(\mathrm{I})$ and $\mathrm{Cu}(\mathrm{II})$ in the copper complexes, e.g., for $m / z 403\left[\mathrm{Cu}^{\mathrm{I}}+2 \mathrm{Cu}^{\mathrm{II}}+6 \mathrm{Cl}\right]^{-}, N_{\mathrm{Cu}(\mathrm{I})}=1$ and $N_{C u(I I)}=2$.

No notable signals of doubly or multiply charged ions in the positive ion mode mass spectra are observed, even though the amount of free electrons was drastically reduced in this case by using a nonmetallic target. This is certainly not a typical MALDI condition. The divalent copper ions that do not undergo reduction are still observed as singly charged complex ions; the charges are simply compensated by $\mathrm{Cl}^{-}$. $\mathrm{Cu}(\mathrm{I})$ is nonetheless observed in the absence of matrix and free electrons, in particular in the positive ion mode spectrum (Figure 1b). Due to the influence of the photons, a homolytic cleavage of $\mathrm{Cu}(\mathrm{II})-\mathrm{Cl}$ bond during the desorption/ionization from the crystal lattice may be possible, which leads to the reduction of $\mathrm{Cu}$ (II) to $\mathrm{Cu}$ (I). As the same results were also obtained when the experiment was done on a ceramic target, the possibility of a reaction with the polymer (PEEK) target can be excluded.

\section{Large Amounts of Free Electrons/No Matrix}

The FT ICR mass spectra of $\mathrm{CuCl}_{2}$ on a stainless steel target using the thin-layer preparation are shown in Figure 2. Figure $2 \mathrm{a}$ is the spectrum obtained in negative ion mode, whereas Figure $2 b$ is obtained in in positive ion mode. Significant differences are shown between the spectra obtained on a metallic (Figure 2) and a nonmetallic target (Figure 1). The signals corresponding to $\mathrm{Cu}(\mathrm{II})$ observed in Figure 1 are hardly seen in Figure 2. In both negative and positive ion mode spectra, $\mathrm{Cu}(\mathrm{I})$ 
Table 1. Composition of the $\mathrm{Cu}_{\mathrm{m}} \mathrm{Cl}_{\mathrm{n}}$ signals observed in all mass spectra acquired in this work

\begin{tabular}{|c|c|c|c|}
\hline & $\begin{array}{c}m / z \text { of the most abundant } \\
\text { isotopic peak }\end{array}$ & $\begin{array}{l}\text { Chemical } \\
\text { formula }\end{array}$ & $\begin{array}{c}\text { Description } \\
\text { (Oxidation states) }\end{array}$ \\
\hline \multirow[t]{25}{*}{ Negative mode } & 135 & {$\left[\mathrm{CuCl}_{2}\right]^{-}$} & {$\left[\mathrm{Cu}^{\prime}+2 \mathrm{Cl}\right]^{-}$} \\
\hline & 170 & {$\left[\mathrm{CuCl}_{3}\right]^{-}$} & {$\left[\mathrm{Cu}^{\prime \prime}+3 \mathrm{Cl}\right]^{-}$} \\
\hline & 198 & {$\left[\mathrm{Cu}_{2} \mathrm{Cl}_{2}\right]^{-}$} & {$\left[\mathrm{Cu}^{0}+\mathrm{Cu}^{1}+2 \mathrm{Cl}\right]^{-}$} \\
\hline & 233 & {$\left[\mathrm{Cu}_{2} \mathrm{Cl}_{3}\right]^{-}$} & {$\left[2 \mathrm{Cu}^{\prime}+3 \mathrm{Cl}\right]^{-}$} \\
\hline & 261 & {$\left[\mathrm{Cu}_{3} \mathrm{Cl}_{2}\right]^{-}$} & {$\left[2 \mathrm{Cu}^{0}+\mathrm{Cu}^{1}+2 \mathrm{Cl}\right]^{-}$} \\
\hline & 270 & {$\left[\mathrm{Cu}_{2} \mathrm{Cl}_{4}\right]^{-}$} & {$\left[\mathrm{Cu}^{\prime}+\mathrm{Cu}^{\prime \prime}+4 \mathrm{Cl}\right]^{-}$} \\
\hline & 296 & {$\left[\mathrm{Cu}_{3} \mathrm{Cl}_{3}\right]^{-}$} & {$\left[\mathrm{Cu}^{0}+2 \mathrm{Cu}^{1}+3 \mathrm{Cl}\right]^{-}$} \\
\hline & 305 & {$\left[\mathrm{Cu}_{2} \mathrm{Cl}_{5}\right]^{-}$} & {$\left[2 \mathrm{Cu}^{\prime \prime}+5 \mathrm{Cl}\right]^{-}$} \\
\hline & 333 & {$\left[\mathrm{Cu}_{3} \mathrm{Cl}_{4}\right]^{-}$} & {$\left[3 \mathrm{Cu}^{\prime}+4 \mathrm{Cl}\right]^{-}$} \\
\hline & 368 & {$\left[\mathrm{Cu}_{3} \mathrm{Cl}_{5}\right]^{-}$} & {$\left[2 \mathrm{Cu}^{\prime}+\mathrm{Cu}^{\prime \prime}+5 \mathrm{Cl}\right]^{-}$} \\
\hline & 396 & {$\left[\mathrm{Cu}_{4} \mathrm{Cl}_{4}\right]^{-}$} & {$\left[\mathrm{Cu}^{0}+3 \mathrm{Cu}^{1}+4 \mathrm{Cl}\right]^{-}$} \\
\hline & 403 & {$\left[\mathrm{Cu}_{3} \mathrm{Cl}_{6}\right]^{-}$} & {$\left[\mathrm{Cu}^{\prime}+2 \mathrm{Cu}^{\prime \prime}+6 \mathrm{Cl}\right]^{-}$} \\
\hline & 431 & {$\left[\mathrm{Cu}_{4} \mathrm{Cl}_{5}\right]^{-}$} & {$\left[4 \mathrm{Cu}^{\prime}+5 \mathrm{Cl}\right]^{-}$} \\
\hline & 440 & {$\left[\mathrm{Cu}_{3} \mathrm{Cl}_{7}\right]^{-}$} & {$\left[3 \mathrm{Cu}^{\prime \prime}+7 \mathrm{Cl}\right]^{-}$} \\
\hline & 462 & {$\left[\mathrm{Cu}_{3} \mathrm{NaCl}_{7}\right]^{-}$} & {$\left[\mathrm{Cu}^{\prime}+2 \mathrm{Cu}^{\prime \prime}+\mathrm{Na}+7 \mathrm{Cl}\right]^{-}$} \\
\hline & 468 & {$\left[\mathrm{Cu}_{4} \mathrm{KCl}_{5}\right]^{-}$} & {$\left[\mathrm{Cu}^{0}+3 \mathrm{Cu}^{1}+\mathrm{K}+5 \mathrm{Cl}\right]^{-}$} \\
\hline & 503 & {$\left[\mathrm{Cu}_{4} \mathrm{Cl}_{7}\right]^{-}$} & {$\left[2 \mathrm{Cu}^{\prime}+2 \mathrm{Cu}^{\prime \prime}+7 \mathrm{Cl}\right]^{-}$} \\
\hline & 528 & {$\left[\mathrm{Cu}_{5} \mathrm{Cl}_{6}\right]^{-}$} & {$\left[5 \mathrm{Cu}^{\prime}+6 \mathrm{Cl}\right]^{-}$} \\
\hline & 538 & {$\left[\mathrm{Cu}_{4} \mathrm{Cl}_{8}\right]^{-}$} & {$\left[\mathrm{Cu}^{\prime}+3 \mathrm{Cu}^{\prime \prime}+8 \mathrm{Cl}\right]^{-}$} \\
\hline & 559 & {$\left[\mathrm{Cu}_{6} \mathrm{Cl}_{5}\right]^{-}$} & {$\left[2 \mathrm{Cu}^{0}+4 \mathrm{Cu}^{1}+5 \mathrm{Cl}\right]^{-}$} \\
\hline & 574 & {$\left[\mathrm{Cu}_{4} \mathrm{Cl}_{9}\right]^{-}$} & {$\left[4 \mathrm{Cu}^{\prime \prime}+9 \mathrm{Cl}\right]^{-}$} \\
\hline & 576 & {$\left[\mathrm{Cu}_{4} \mathrm{KCl}_{8}\right]^{-}$} & {$\left[2 \mathrm{Cu}^{\prime}+2 \mathrm{Cu}^{\prime \prime}+\mathrm{K}+8 \mathrm{Cl}\right]$} \\
\hline & 638 & {$\left[\mathrm{Cu}_{5} \mathrm{Cl}_{9}\right]^{-}$} & {$\left[2 \mathrm{Cu}^{\prime}+3 \mathrm{Cu}^{\prime \prime}+9 \mathrm{Cl}\right]^{-}$} \\
\hline & 673 & {$\left[\mathrm{Cu}_{5} \mathrm{Cl}_{10}\right]^{-}$} & {$\left[\mathrm{Cu}^{\prime}+4 \mathrm{Cu}^{\prime \prime}+10 \mathrm{Cl}\right]^{-}$} \\
\hline & 770 & {$\left[\mathrm{Cu}_{6} \mathrm{Cl}_{11}\right]^{-}$} & {$\left[2 \mathrm{Cu}^{\prime}+4 \mathrm{Cu}^{\prime \prime}+11 \mathrm{Cl}\right]^{-}$} \\
\hline \multirow[t]{14}{*}{ Positive mode } & 163 & {$\left[\mathrm{Cu}_{2} \mathrm{Cl}\right]^{+}$} & {$\left[2 \mathrm{Cu}^{\prime}+\mathrm{Cl}\right]^{+}$} \\
\hline & 187 & {$\left[\mathrm{Cu}_{2} \mathrm{NaCl}\right]^{+}$} & {$\left[\mathrm{Cu}^{0}+\mathrm{Cu}^{1}+\mathrm{Na}+\mathrm{Cl}^{+}\right.$} \\
\hline & 261 & {$\left[\mathrm{Cu}_{3} \mathrm{Cl}_{2}\right]^{+}$} & {$\left[3 \mathrm{Cu}^{\prime}+2 \mathrm{Cl}\right]^{+}$} \\
\hline & 287 & {$\left[\mathrm{Cu}_{3} \mathrm{NaCl}_{2}\right]^{+}$} & {$\left[2 \mathrm{Cu}^{0}+\mathrm{Cu}^{1}+\mathrm{Na}+2 \mathrm{Cl}\right]$} \\
\hline & 298 & {$\left[\mathrm{Cu}_{3} \mathrm{Cl}_{3}\right]^{+}$} & {$\left[2 \mathrm{Cu}^{\prime}+\mathrm{Cu}^{\prime \prime}+3 \mathrm{Cl}\right]^{+}$} \\
\hline & 360 & {$\left[\mathrm{Cu}_{4} \mathrm{Cl}_{3}\right]^{+}$} & {$\left[4 \mathrm{Cu}^{\prime}+3 \mathrm{Cl}\right]^{+}$} \\
\hline & 396 & {$\left[\mathrm{Cu}_{4} \mathrm{Cl}_{4}\right]^{+}$} & {$\left[3 \mathrm{Cu}^{\prime}+\mathrm{Cu}^{\prime \prime}+4 \mathrm{Cl}\right]^{+}$} \\
\hline & 431 & {$\left[\mathrm{Cu}^{4} \mathrm{Cl}_{5}\right]^{+}$} & {$\left[2 \mathrm{Cu}^{\prime}+2 \mathrm{Cu}^{\prime \prime}+5 \mathrm{Cl}\right]^{+}$} \\
\hline & 459 & {$\left[\mathrm{Cu}_{5} \mathrm{Cl}_{4}\right]^{+}$} & {$\left[5 \mathrm{Cu}^{\prime}+4 \mathrm{Cl}\right]^{+}$} \\
\hline & 495 & {$\left[\mathrm{Cu}_{5} \mathrm{Cl}_{5}\right]^{+}$} & {$\left[4 \mathrm{Cu}^{\prime}+\mathrm{Cu}^{\prime \prime}+5 \mathrm{Cl}\right]^{+}$} \\
\hline & 531 & {$\left[\mathrm{Cu}_{5} \mathrm{Cl}_{6}\right]^{+}$} & {$\left[3 \mathrm{Cu}^{\prime}+2 \mathrm{Cu}^{\prime \prime}+6 \mathrm{CI}\right]^{+}$} \\
\hline & 559 & {$\left[\mathrm{Cu}_{6} \mathrm{Cl}_{5}\right]^{+}$} & {$\left[6 \mathrm{Cu}^{\prime}+5 \mathrm{Cl}\right]^{+}$} \\
\hline & 594 & {$\left[\mathrm{Cu}_{6} \mathrm{Cl}_{6}\right]^{+}$} & {$\left[5 \mathrm{Cu}^{\prime}+\mathrm{Cu}^{\prime \prime}+6 \mathrm{Cl}\right]^{+}$} \\
\hline & 630 & {$\left[\mathrm{Cu}_{6} \mathrm{Cl}_{7}\right]^{+}$} & {$\left[4 \mathrm{Cu}^{\prime}+2 \mathrm{Cu} \mathrm{u}^{\prime \prime}+7 \mathrm{Cl}\right]^{+}$} \\
\hline
\end{tabular}

signals are dominant, i.e., $m / z 233\left(\left[2 \mathrm{Cu}^{\mathrm{I}}+3 \mathrm{Cl}\right]^{-}\right)$in the negative ion mode spectrum (Figure $2 \mathrm{a}$ ), and $\mathrm{m} / \mathrm{z} 163$ $\left(\left[2 \mathrm{Cu}^{\mathrm{I}}+\mathrm{Cl}\right]^{+}\right)$as well as $m / z 261\left(\left[3 \mathrm{Cu}^{\mathrm{I}}+2 \mathrm{Cl}\right]^{+}\right)$in the positive ion mode spectrum (Figure $2 b$ ). The ratios of $\mathrm{Cu}(\mathrm{I}) / \mathrm{Cu}(\mathrm{II})$ in negative and positive ion mode are 132.3 and 204.9, respectively, i.e., copper is present in reduced form almost exclusively. By using a metallic target and thin-layer sample preparation there are many more photoelectrons produced than where a nonmetallic target is used [23, 24]. Since there is no other experimental conditions that was changed, the substantial reduction of $\mathrm{Cu}(\mathrm{II})$ to $\mathrm{Cu}(\mathrm{I})$, and even to $\mathrm{Cu}(0)$ must be caused by the large amount of free electrons produced by photoelectric emission from the metal $/ \mathrm{CuCl}_{2}$ interface. Compared to the signals obtained on the nonmetallic target, the abundance of clusters with masses above $400 \mathrm{Da}$ is also drastically reduced.

When the metallic target was covered by a thick layer of $\mathrm{CuCl}_{2}$, mass spectra that are similar as those in Figure 1 with dominant $\mathrm{Cu}(\mathrm{II})$ signals were obtained. A general observation in MALDI mass spectrometry is that the intensity of spectra obtained from different spots of the sample surface can vary considerably. Based on the findings discussed here we hypothesize that this is a result of the strongly varying thickness of a typical MALDI sample, i.e., there will be large crystals as well as areas that are almost bare. Thus, the yield of emitted electrons will also vary strongly as a function of location, dramatically affecting the efficiency of positive charge reduction and neutralization by electrons.

\section{With Matrix Present/No Free Electrons}

Figure 3 shows the FT MS spectra of $\mathrm{CuCl}_{2}+$ matrix (matrix = nicotinic acid, Figure $3 a, b$; dithranol, Figure 3c, d; 2,5-dihydroxybenzoic acid, Figure. 3e, f) obtained on a nonmetallic (PEEK) target in both positive and 

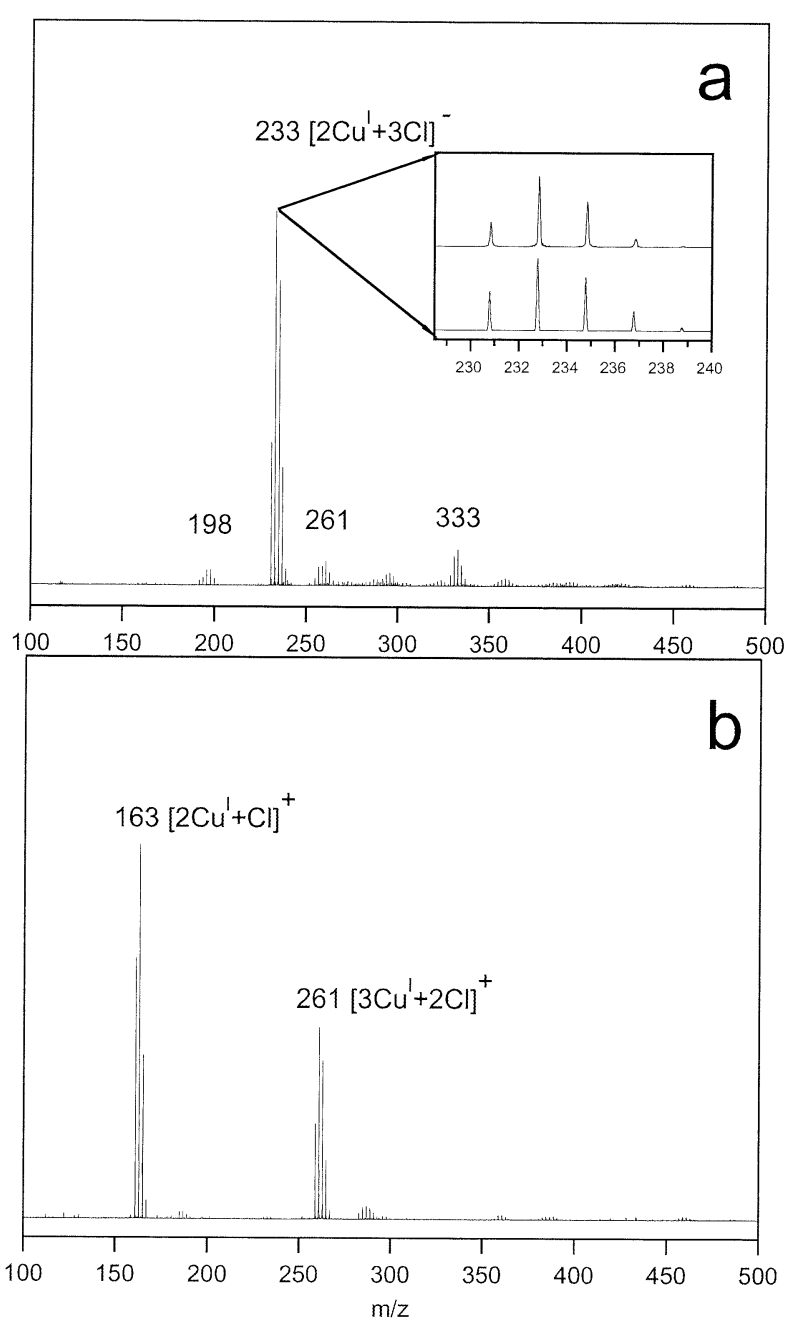

Figure 2. FT MS mass spectra obtained by direct laser desorption/ionization of $\mathrm{CuCl}_{2}$ on a metallic target. (a) Negative ion mode, (b) positive ion mode. Inset: Magnification of peak at $\mathrm{m} / \mathrm{z}$ 233 (upper trace) and the calculated isotope distribution (lower trace).

negative ion mode. From Figure 3 on, the labeling of peaks is simplified for clarity. The complete composition of the $\mathrm{Cu}_{\mathrm{m}} \mathrm{Cl}_{\mathrm{n}}$ cluster signals is given in Table 1. In general, we found that the copper/chloride cluster signals were dominant in the negative ion mode mass spectra, whereas matrix signals are observed in the positive ion mode mass spectra. The $\left[\mathrm{Cu}_{\mathrm{m}} \mathrm{Cl}_{\mathrm{n}}\right]^{+}$signals appear to be suppressed in positive ion mode when matrices are present. Apparently, matrix molecules and matrix anions can be better ligands for copper than $\mathrm{Cl}^{-}$.

In the negative ion mode mass spectra, the most intense signal represents $\mathrm{Cu}(\mathrm{I})$ at $\mathrm{m} / \mathrm{z} 233\left(\left[2 \mathrm{Cu}^{\mathrm{I}}+\right.\right.$ $3 \mathrm{Cl}]^{-}$). Comparing the negative signals of $\mathrm{Cu}_{\mathrm{m}} \mathrm{Cl}_{\mathrm{n}}$ in the presence of three different matrices, we can see that the reduction of $\mathrm{Cu}(\mathrm{II})$ is much more efficient with nicotinic acid, whereas when dithranol or 2,5-dihydroxybenzoic acid are used as matrix there are still relatively intense signals representing $\mathrm{Cu}(\mathrm{II})$, e.g., $\mathrm{m} / z 305\left(\left[2 \mathrm{Cu}^{\mathrm{II}}+\right.\right.$ $\left.5 \mathrm{Cl}]^{-}\right), m / z 403\left(\left[\mathrm{Cu}^{\mathrm{I}}+2 \mathrm{Cu}^{\mathrm{II}}+6 \mathrm{Cl}\right]^{-}\right)$, etc. The $\mathrm{Cu}(\mathrm{I}) /$ $\mathrm{Cu}$ (II) ratio in the negative ion mode mass spectra are
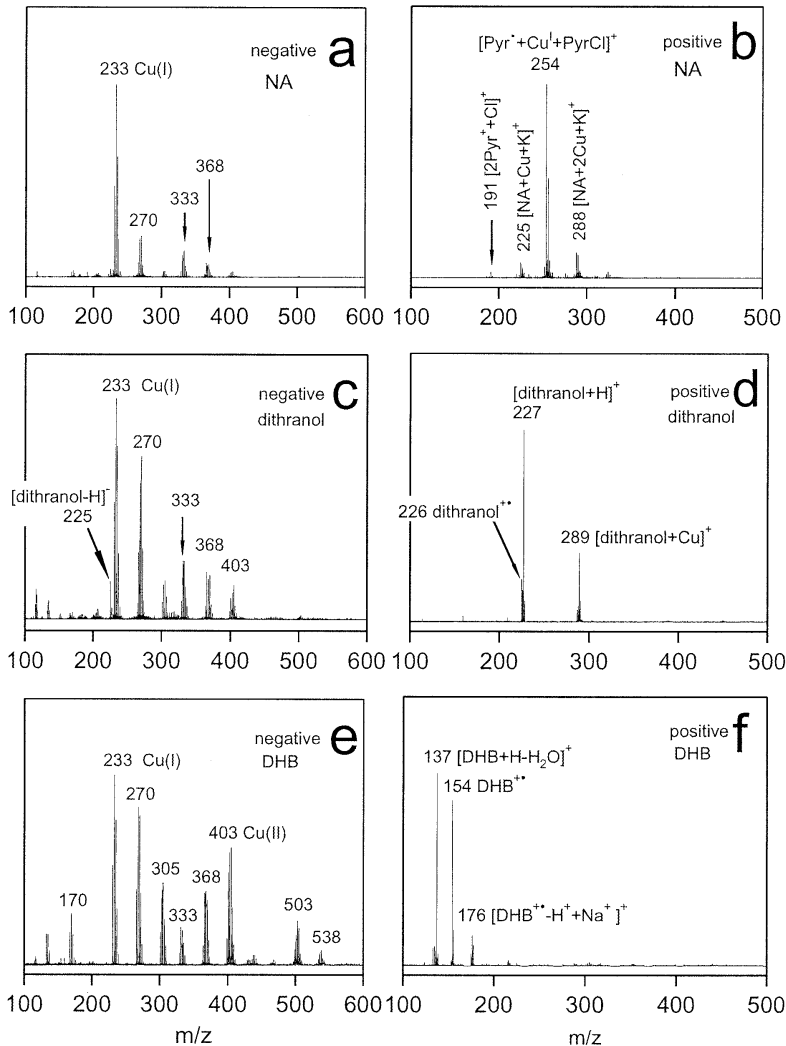

Figure 3. MALDI FT MS spectra of $\mathrm{CuCl}_{2}$ obtained by laser desorption on a PEEK target. The matrices employed were nicotinic acid (a), (b); dithranol (c), (d); and 2,5-dihydroxybenzoic acid (e), (f).

6.6 for nicotinic acid (Figure 3a), 4.0 for dithranol (Figure 3c), and 1.2 for 2,5-dihydroxybenzoic acid (Figure $3 \mathrm{e})$.

As Knochenmuss et al. have pointed out, the charge transfer reaction (reaction 2) in the gas phase between $\mathrm{Cu}(\mathrm{II})$ and neutral MALDI matrices can take place because the reaction is exothermic [22]. The ionization potentials (IP) of the matrices are $9.38 \mathrm{eV}$ for nicotinic acid [30] and $8.05 \mathrm{eV}$ for 2,5-dihydroxybenzoic acid [31]. The IP of dithranol is $7.9 \mathrm{eV}$ obtained by our ab initio calculation. Since there is no experimental data for IP of dithranol available, a parallel calculation was done for nicotinic acid. The calculated IP of nicotinic acid is 9.24 $\mathrm{eV}$, only $0.16 \mathrm{eV}(1.5 \%)$ less than the experimental value. This good agreement gives confidence in the IP calculation of dithranol. We remark that more accurate computations may be obtained by higher level calculations. The first and the second IPs of copper are 7.73 and 20.29 [32]. The IPs show that all three matrices are able to reduce $\mathrm{Cu}(\mathrm{II})$ to $\mathrm{Cu}(\mathrm{I})$ as shown in reaction 2, where $\mathrm{m}$ is matrix. This reaction is exothermic by $10.91 \mathrm{eV}$ for nicotinic acid, $12.24 \mathrm{eV}$ for 2,5-dihydroxybenzoic acid, and $12.4 \mathrm{eV}$ for dithranol.

$$
m+C u^{++} \rightarrow m^{++}+C u^{+}
$$

In the positive ion mode spectrum (Figure $3 b$ ) of $\mathrm{CuCl}_{2}$ 
+ NA, the most intense peak is $m / z 254$. By observing the fragments from the ions at $m / z 254$ and $m / z 191$ by both FT ICR MS and TOF MS, a signal at $m / z 78$ showed up in the positive ion mode, which is a fragment of nicotinic acid [NA-COOH $]^{+}\left(=[\text {Pyridine- } \mathrm{H}]^{+}\right.$, abbreviated $\mathrm{Pyr}^{+}$in this work; its corresponding neutral radical is Pyr). Together with the simulated isotope distribution, the two signal $m / z 191$ and $m / z 254$ could be assigned to $\left[\mathrm{Pyr}^{+}+\mathrm{Cl}+\mathrm{Pyr}^{+}\right]^{+}$and $\left[\mathrm{Pyr}+\mathrm{Cu}^{\mathrm{I}}+\right.$ $\mathrm{PyrCl}^{+}(\mathrm{PyrCl}=3-\mathrm{Chloropyridine})$, indicating that the reduction of $\mathrm{Cu}(\mathrm{II})$ is accompanied by fragmentation of nicotinic acid (reaction 3 ).

$$
\mathrm{NA}^{\cdot+} \rightarrow \mathrm{Pyr}^{\cdot}+\mathrm{COOH}^{+}
$$

Pyr can loose an electron if an oxidant is available, e.g., $\mathrm{Cu}(\mathrm{II})$. We have also estimated the ionization potential of Pyr to be $8.4 \mathrm{eV}$ by ab initio calculations. This value is lower than the second IP of copper (20.29 $\mathrm{eV})$. Therefore, reaction 4 is exothermic by about $12 \mathrm{eV}$.

$$
P y r+C u^{++} \rightarrow \mathrm{Pyr}^{+}+\mathrm{Cu} u^{+}
$$

Not only nicotinic acid can reduce $\mathrm{Cu}$ (II) (reaction 2), but also its fragment Pyr (reaction 4). In other words, one nicotinic acid molecule can reduce two divalent copper ions. In addition, the fragmentation of the nicotinic acid radical cation can push the equilibrium of reaction 2 to the right side. These might be the reasons why nicotinic acid gives higher reduction efficiency than the other two matrices.

For a $12.4 \mathrm{eV}$ energy gain in reaction 1 , the reduction of $\mathrm{Cu}$ (II) is certainly allowed for dithranol. This can be seen in the negative ion mode mass spectra in Figure 3c, where the most intense signal is presented by the reduced form of copper. In the positive ion mode (Figure 3d) dithranol gives a relatively strong signal of a dithranol-Cu(I) complex $(\mathrm{m} / z$ 289). The most intense signal is, however, the protonated dithranol ( $m / z 227)$. A certain amount of dithranol ${ }^{-+}(m / z 226)$, which can be the product of the reduction of $\mathrm{Cu}(\mathrm{II})$, shows up in the positive ion mode spectrum next to the protonated dithranol.

The reduction of $\mathrm{Cu}(\mathrm{II})$ is also highly exothermic $(-12.24 \mathrm{eV}$ reaction energy), if 2,5-dihydroxybenzoic acid is used as the matrix. The radical cation of 2,5dihydroxybenzoic acid $\left([\mathrm{DHB}]^{++}\right.$at $\left.\mathrm{m} / \mathrm{z} 154\right)$ shows up with very high intensity in the positive ion mode mass spectra (Figure 3f). In addition to the multiphoton ionization process of DHB itself [33], the reduction of $\mathrm{Cu}$ (II) by $\mathrm{DHB}$ molecule is another source of this positive radical ion. The intensity of protonated DHB signal at $m / z 155$ is not very high, instead, the signal of the fragment $\left[\mathrm{DHB}+\mathrm{H}-\mathrm{H}_{2} \mathrm{O}\right]^{+}$at $m / z 137$ is the most intense peak. There is no sign of a reaction similar to reaction 3 taking place. The signal at $\mathrm{m} / \mathrm{z} 176$ is identified as $[\mathrm{DHB}-\mathrm{H}+\mathrm{Na}]^{+}$. Sodiated matrix signals are often observed in the positive ion mode MALDI spectra (for instance, $[\mathrm{DHB}+\mathrm{Na}]^{+}$at $m / z$ 177), but hydrogen radical loss from sodiated $\mathrm{DHB}$ is not usual. For this reason, we consider $[\mathrm{DHB}-\mathrm{H}+\mathrm{Na}]^{+}$to be a product of the DHB radical cation $\left([\mathrm{DHB}]^{+}\right)$attaching a sodium ion after losing a proton, rather than being formed by $\mathrm{H}^{*}$ loss from $[\mathrm{DHB}+\mathrm{Na}]^{+}$.

A small amount of signals representing $\mathrm{Cu}(0)$ emerge in the positive ion mode spectrum (Figure $3 b$, $m / z 288$ ). As mentioned above, the IPs of matrices are much lower than the second IP of copper but higher than the first IP. Therefore, the reaction in which $\mathrm{Cu}(\mathrm{I})$ is reduced to $\mathrm{Cu}(0)$ is endothermic. In this case, the emergence of $\mathrm{Cu}(0)$ might be due to a minor amount of free electrons in the plume, although the major free electron source was blocked by using a nonmetallic target. This small amount of free electrons is produced by the laser desorption processes, and is ca. $1 \%$ of the free electrons produced by the photoelectric emission from the metal/matrix interface [24]. Another reason for this can also be the homolytic bond cleavage initiated by the laser photons, as discussed in an earlier section.

All three matrices are able to reduce $\mathrm{Cu}(\mathrm{II})$ to $\mathrm{Cu}(\mathrm{I})$ by charge transfer provided that there are enough collisions in the MALDI plume. By reducing the laser pulse energy, the plume density is decreased. The number of collisions between the species in the plume is therefore also reduced. Figure 4 shows the negative mass spectra of $\mathrm{CuCl}_{2}+$ matrix (matrix $=$ nicotinic acid, 4a; dithranol, 4b; 2,5-dihydroxybenzoic acid, 4c) obtained by using low laser pulse energy on a nonmetallic target. Comparing the negative ion mode spectra in Figure 3a, c, and e and those in the Figure 4, a notable difference is that the most intense signals in Figure 4 are those of $\mathrm{Cu}(\mathrm{II})$, whereas in Figure 3 the $\mathrm{Cu}(\mathrm{I})$ signals are dominant. The fact that signals of $\mathrm{Cu}(\mathrm{II})$ are dominant at low laser pulse energy strongly suggests that the reduction of $\mathrm{Cu}(\mathrm{II})$ takes place in the gas phase. Figure 5 shows the dependence of laser pulse energy in the reduction of $\mathrm{Cu}(\mathrm{II})$. By decreasing the laser pulse energy, the signal at $m / z 233$, representing $\mathrm{Cu}(\mathrm{I})$ exclusively, is decreased, whereas the signal at $m / z 403$ $(\mathrm{Cu}(\mathrm{II}))$, is increased (Figure 5a). If the laser pulse energy is decreased, the gas-phase charge transfer reaction rate is decreased because of insufficient collision in the plume. This can be clearly seen in Figure 5b showing the normalized intensity of signals containing $\mathrm{Cu}(\mathrm{I})$ and $\mathrm{Cu}(\mathrm{II})$ as a function of laser pulse energy.

\section{TOF MS Experiments}

TOF MS experiments were carried out using continuous extraction and delayed extraction. Both with large amounts of free electrons and in the presence of matrix, $\mathrm{Cu}(\mathrm{II})$ is largely reduced. The TOF mass spectra were found to be quite similar to the FT ICR data with respect to the reduction of $\mathrm{Cu}(\mathrm{II})$ (data not shown). Field free conditions (delayed extraction and FT ICR experiments) may allow all the species in the MALDI plume to 

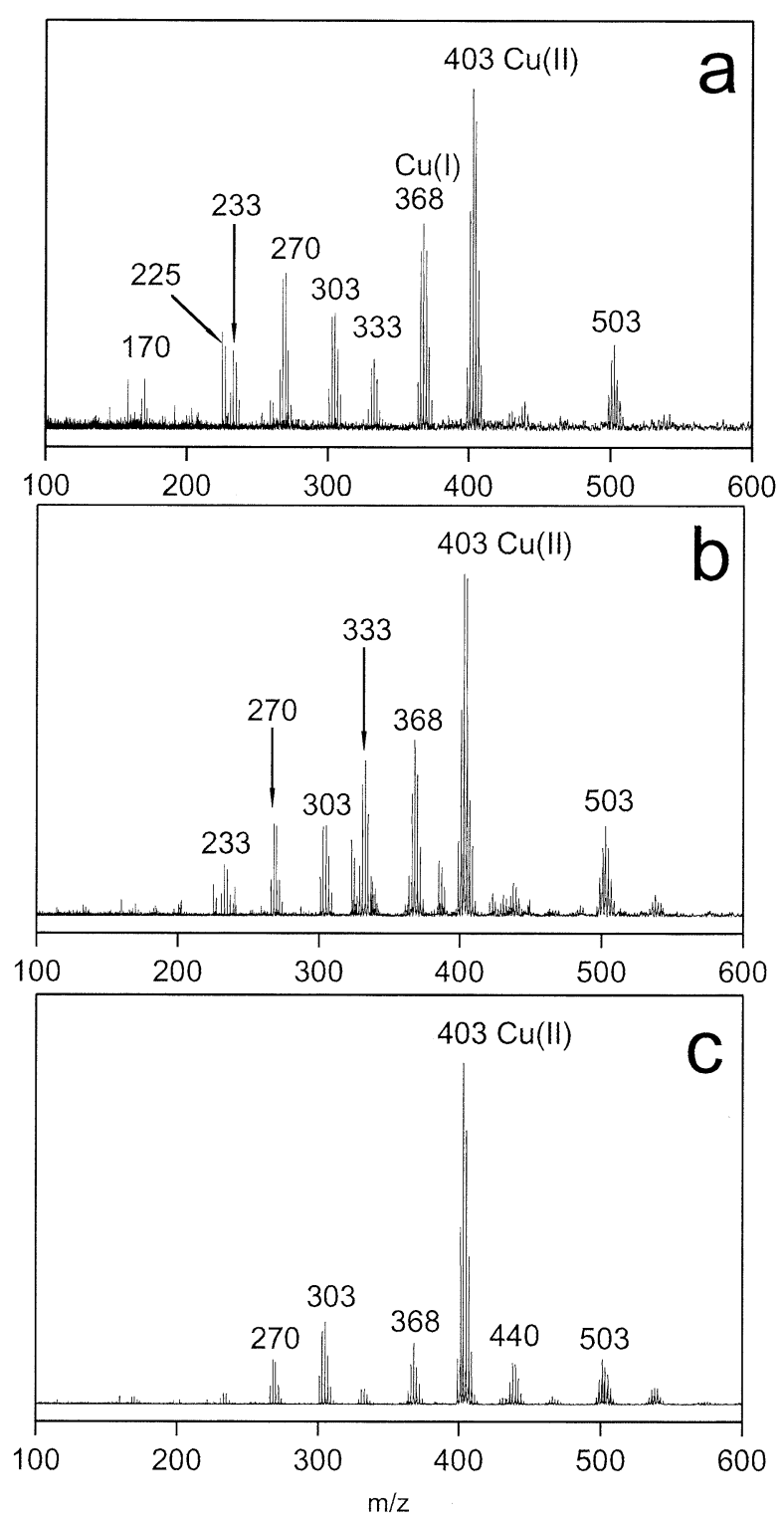

Figure 4. Negative ion mode MALDI FT MS spectra of $\mathrm{CuCl}_{2}$ obtained by laser desorption on a PEEK target. Matrix = nicotinic acid (a); dithranol (b); 2,5-dihydroxybenzoic acid (c). Low laser pulse energy was employed.

undergo gas-phase reactions, e.g., electron capture and charge exchange reactions. Therefore, less reduction of $\mathrm{Cu}(\mathrm{II})$ under $\mathrm{CE}$ condition might be expected. However, data obtained from TOS MS experiments did not show significant differences under continuous extraction and delayed extraction conditions with respect to the reduction of copper. The penetration depth of the electrons with $2 \mathrm{eV}$ energy (see reference [24]) in a $+20 \mathrm{kV}$ retarding potential is about $10 \mu \mathrm{m}$. This is enough for the neutralization and electron capture reactions to occur. Continuous extraction may lead to less frequent gas-phase reactions. It is, however, not possible to suppress gas-phase reactions by using continuous extraction fields.
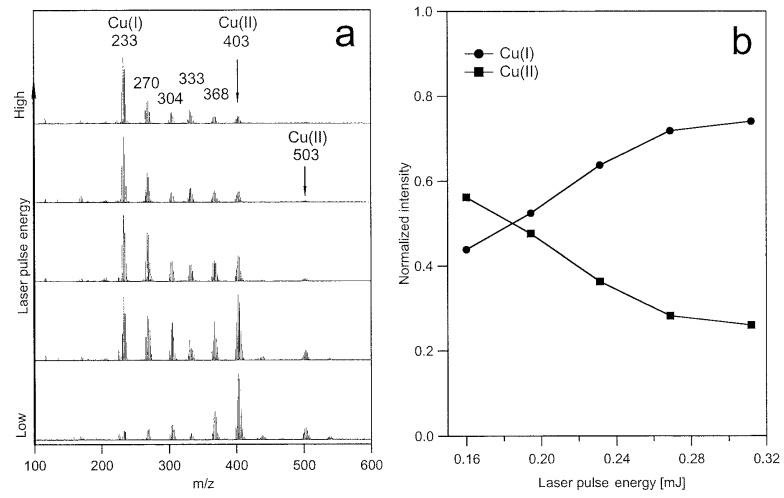

Figure 5. (a) Negative ion mode MALDI mass spectra of $\mathrm{CuCl}_{2}$ with nicotinic acid as matrix obtained on a nonmetallic target. The higher the laser pulse energy, the more $\mathrm{Cu}(\mathrm{II})$ is reduced to $\mathrm{Cu}(\mathrm{I})$. (b) The normalized intensities of signals corresponding to $\mathrm{Cu}(\mathrm{I})$ and $\mathrm{Cu}(\mathrm{II})$ as a function of laser pulse energy.

\section{Reduction of Multivalent Metal Ions in ESI, FAB, and SIMS}

Reduction of multivalent metal ions has also been observed in other MS techniques, e.g., electrospray ionization (ESI), fast atom bombardment (FAB), and secondary ion mass spectrometry (SIMS). Gianelli et al. have studied reduction of $\mathrm{Cu}(\mathrm{II})$ complexes in positive ion mode ESI MS [34]. They found that the reduction is not a usual ESI electrochemical redox reaction. In fact, the reduction occurs in the gas phase by an electron transfer between a Cu complex and a solvent molecule. They also found a correlation between the ionization energy of the solvent and the reduction yield. Therefore, solvent molecules are the reduction agents in ESI, while in MALDI both matrix molecules and free electrons play a role. The thermochemistry is analogous in both cases if only matrix (in MALDI) and solvent molecules (in ESI) are considered, since the second IP of copper exceeds the ionization energies of most organic compounds (including solvents used in ESI or MALDI matrices) and even of water. The differences of these two techniques in terms of reduction of $\mathrm{Cu}$ (II) are the gas-phase conditions. First, the high density in the MALDI plume provides more favorable conditions for gas-phase reactions than ESI; second, exited matrix molecules may be involved in the reaction, which obviously has energetic advantages; and finally, there can be large amount of free electrons in MALDI plume that are the most efficient reduction agent. The latter may be also one of the reasons why singly charged ions are dominant in MALDI MS while multiply charged ions are common in ESI MS. In reference [34], the electrochemical reduction potential of the complexes in solution was also found to be an important parameter for the reduction of $\mathrm{Cu}(\mathrm{II})$, which is more relevant for ESI than for MALDI. The multivalent metal ions can undergo gas-phase reduction, provided that the charges are stabilized, e.g., by polydentate ligands [34].

Matrix-assisted one-electron reduction processes 
may also be responsible for the production of singly charged ions and lowering of the oxidation state of metal ions in particle bombardment methods such as FAB and SIMS (see for example [35-37]). However, some workers have interpreted the reduction of multivalent metal ions as a liquid phase process in FAB and SIMS. Pelzer et al. have observed the following reductions in SIMS and FAB spectra obtained by using glycerol as matrix: $\mathrm{Cr}(\mathrm{III}) \rightarrow \mathrm{Cr}(\mathrm{II}), \mathrm{Cu}(\mathrm{II}) \rightarrow \mathrm{Cu}(\mathrm{I})$, and $\mathrm{Fe}(\mathrm{III}) \rightarrow \mathrm{Fe}$ (II). The fact that Fe(III) was found to be reduced to $\mathrm{Fe}(\mathrm{II})$ more extensively than $\mathrm{Cr}$ (III) to $\mathrm{Cr}$ (II) cannot be explained by the redox potential of $\mathrm{Fe}^{3+} / \mathrm{Fe}^{2+}$ and $\mathrm{Cr}^{3+} / \mathrm{Cr}^{2+}$ [36]. In the system studied by FAB using liquid matrices, Martínez-Díaz et al. have found that the reduction is always accompanied by fragmentation (ligand loss) and concomitant stabilization of the resulting metal complexes [37]. No doubly charged ions were observed for the complexes studied no matter whether an oxidizing matrix, e.g., m-nitrobenzyl alcohol (mNBA) was used instead of glycerol. A similar situation may exist in MALDI or LDI mass spectrometry of metal complexes. Further investigation must be done for more detailed comparison of the different mass spectrometric techniques.

\section{Conclusions}

(1) $\mathrm{Cu}(\mathrm{II})$ is reduced in the absence of free electrons by gas-phase charge exchange with matrix molecules. This is a thermodynamically favorable process. A high plume density is required in this case. Both nicotinic acid and its decarboxylated fragment can take part in the reduction of $\mathrm{Cu}(\mathrm{II})$. This makes the reduction more efficient than for dithranol and 2,5-dihydroxybenzoic acid. (2) Free electron capture is the dominant mechanism for reduction of $\mathrm{Cu}(\mathrm{II})$, provided that there are enough free electrons available in the MALDI plume. A relatively thick matrix layer, or a large crystallite can easily block this source of free electrons. This might even explain the often poor reproducibility of MALDI mass spectra. (3) Time-of-flight experiments show that a high extraction field does not influence the reduction of $\mathrm{Cu}$ (II) in both cases, i.e., the free electron capture and charge exchange with matrix.

\section{Acknowledgments}

The authors thank Patrick Dietemann for useful discussions. They also acknowledge the generous allocation of computer time by Informatikdienste der ETHZ (Stardust).

\section{References}

1. Karas, M.; Bachmann, D.; Bahr, U.; Hillenkamp, F. MatrixAssisted Ultraviolet-Laser Desorption of Nonvolatile Compounds. Int. J. Mass Spectrom. Ion. Processes 1987, 78, 53-68.

2. Karas, M.; Bahr, U.; Giessmann, U. Matrix-Assisted Laser Desorption Ionization Mass-Spectrometry. Mass Spectrom. Rev. 1991, 10, 335-357.
3. Belu, A. M.; DeSimone, J. M.; Linton, R. W.; Lange, G. W.; Friedman, R. M. Evaluation of Matrix-Assisted Laser Desorption/Ionization Mass Spectrometry for Polymer Characterization. J. Am. Soc. Mass Spectrom. 1996, 7, 11-24.

4. Nielen, M. W. F. MALDI Time-of-Flight Mass Spectrometry of Synthetic Polymers. Mass Spectrom. Rev. 1999, 18, 309-344.

5. Montaudo, G.; Montaudo, M. S.; Puglisi, C.; Samperi, F. Characterization of Polymers by Matrix-Assisted Laser Desorption Ionization Time-of-Flight Mass-Spectrometry Molecular-Weight Estimation in Sample of Varying Polydispersity. Rapid Commun. Mass Spectrom. 1995, 9, 453-460.

6. Bahr, U.; Deppe, A.; Karas, M.; Hillenkamp, F.; Giessmann, U. Mass-Spectrometry of Synthetic-Polymers by UV Matrix-Assisted Laser Desorption Ionization. Anal. Chem. 1992, 64, 2866-2869.

7. Dey, M.; Castoro, J. A.; Wikins, C. L. Determination of Molecular-Weight Distributions of Polymers by MALDIFTMS. Anal. Chem. 1995, 67, 1575-1579.

8. Danis, P. O.; Karr, D. E.; Mayer, F.; Holle, A. The Analysis of Water-Soluble Polymers by Matrix-Assisted Laser Desorption/Ionization Mass-Spectrometry. Org. Mass Spectrom. 1992, 27, 843-846.

9. Hillenkamp, F.; Karas, M.; Beavis, R. C.; Chait, B. T. MatrixAssisted Laser Desorption Ionization Mass-Spectrometry of Biopolymers. Anal. Chem. 1991, 63, 1193-1202.

10. Wang, B. H.; Dreisewerd, K.; Bahr, U.; Karas, M.; Hillenkamp, F. Gas-Phase Cationization and Protonation of Neutrals Generated by Matrix-Assisted Laser Desorption. J. Am. Soc. Mass Spectrom. 1993, 4, 393-398.

11. Nelson, R. W.; Hutchens, T. W. Mass-Spectrometric Analysis of Transition-Metal-Binding Peptide Using Matrix-Assisted Laser Desorption Ionization Time-of-Flight Mass-Spectrometry-A Demonstration of Probe Tip Chemistry. Rapid Commun. Mass Spectrom. 1992, 6, 4-8.

12. Wong, C. K. L.; Chan, T.-W. D. Cationization Proceses in Matrix-Assisted Laser Desorption/Ionization Mass Spectrometry: Attachment of Divalent and Trivalent Metal Ions. Rapid Commun. Mass Spectrom. 1997, 11, 513-519.

13. Deery, M. J.; Jennings, K. R.; Jasieczek, C. B.; Haddleton, D. M.; Jackson, A. T.; Yates, H. T.; Scrivens, J. H. A Study of Cation Attachment to Polystyrene by Means of Matrix-Assisted Laser Desorption/Ionization and Electrospray Ionization-Mass Spectrometry. Rapid Commun. Mass Spectrom. 1997, 11, 57-62.

14. Lehmann, E.; Knochenmuss, R.; Zenobi, R. Ionization Mechanisms in Matrix-Assisted Laser Desorption/Ionization Mass Spectrometry: Contribution of Preformed Ions. Rapid Commun. Mass Spectrom. 1997, 11, 1483-1492.

15. Yalcin, T.; Schriemer, D. C.; Li, L. Matrix-Assisted Laser Desorption/Ionization Time-of-Flight Mass Spectrometry for the Analysis of Polydienes. J. Am. Soc. Mass Spectrom. 1997, 8, $1220-1229$.

16. Knochenmuss, R.; Lehmann, E.; Zenobi, R. Polymer Cationization in Matrix-Assisted Laser Desorption/Ionization. Eur. Mass Spectrom. 1998, 4, 421-427.

17. Salih, B.; Masselon, C.; Zenobi, R. Matrix-Assisted Laser Desorption/Ionization Mass Spectrometry of Noncovalent Protein-Transition Metal Ion Complexes. J. Mass Spectrom. 1998, 33, 994-1002.

18. Rashidezadeh, H.; Hung, K.; Guo, B. Probing Polystyrene Cationization in Matrix-Assisted Laser Desorption/Ionization. Eur. Mass Spectrom. 1998, 4, 429-433.

19. Masselon, C.; Salih, B.; Zenobi, R. Matrix-Assisted Laser Desorption/Ionization Fourier Transform Mass Spectrometry of Luteinizing Hormone Releasing Hormone-Metal Ion Complexes. J. Am. Soc. Mass Spectrom. 1999, 10, 19-26.

20. Woods, A. S.; Buchsbaum, J. C.; Worrall, T. A.; Berg, J. M.; Cotter, R. J. Matrix-Assisted Laser Desorption/Ionization 
Noncovalently Bound Compounds. Anal. Chem. 1995, 67, 4462-4465.

21. Karas, M.; Glückmann, M.; Schäfer, J. Ionization in MatrixAssisted Laser Desorption/Ionization: Singly Charged Molecular Ions are the Lucky Survivors. J. Mass Spectrom. 2000, 35, 1-12.

22. Knochenmuss, R.; Stortelder, A.; Breuker, K.; Zenobi, R. Secondary Ion-Molecule Reactions in Matrix-Assisted Laser Desorption/Ionization. J. Mass Spectrom. 2000, 35, 1237-1245.

23. Gorshkov, M. V.; Frankevich, V.; Zenobi, R. Characteristics of Photoelectrons Emitted in Matrix-Assisted Laser Desorption/ Ionization Fourier Transform Ion Cyclotron Resonance Experiments. Eur. J. Mass Spectrom. 2002, 8, 67-69.

24. Frankevich, V.; Knochenmuss, R.; Zenobi, R. The Origin of Electrons in MALDI and their Use of Sympathetic Cooling of Negative Ions in MALDI FTICR. Int. J. Mass Spectrom. 2002, 220, 11-19.

25. Frankevich, V.; Zenobi, R. Flexible Open-Cell Design for Internal-Source Matrix-Assisted Laser Desorption/Ionization Fourier Transform Ion Cyclotron Resonance Mass Spectrometry. Rapid Commun. Mass Spectrom. 2001, 15, 979-985.

26. Becke, A. D. Density-Functional Thermochemistry. III. The Role of Exact Exchange. J. Chem. Phys. 1993, 98, 5648-5652.

27. Becke, A. D. A New Mixing of Hartree-Fock and Local Density-Functional Theories. J. Chem. Phys. 1993, 98, 13721377.

28. Lee, C.; Yang, W.; Parr, R. G. Development of the ColleSalvetti Correlation-Energy Formula into a Functional of the Electron Density. Phys. Rev. B 1988, 37, 785-789.

29. Frisch, M. J.; Trucks, G. W.; Schlegel, H. B.; Scuseria, G. E.; Robb, M. A.; Cheeseman, J. R.; Zakrzewski, V. G.; Montgomery, Jr., J.; Stratmann, R. E.; Burant, J. C.; Dapprich, S.; Millam, J. M.; Daniels, A. D.; Kudin, K. N.; Strain, M. C.; Farkas, O.; Tomasi, J.; Barone, V.; Cossi, M.; Cammi, R.; Mennucci, B. C.; Pomelli, C.; Adamo, C.; Clifford, S.; Ochterski, J.; Petersson, G. A.; Ayala, P. Y.; Cui, Q.; Morokuma, K.; Malick, D. K.;
Rabuck, A. D.; Raghavachari, K.; Foresman, J. B.; Cioslowski, J.; Ortiz, J. V.; Baboul, A. G.; Stefanov, B. B.; Liu, G.; Liashenko, A.; Piskorz, P.; Komaromi, I.; Gomperts, R.; Martin, R. L.; Fox, D. J.; Keith, T.; Al-Laham, M. A.; Peng, C. Y.; Nanayakkara, A.; Challacombe, M.; Gill, P. M. W.; Johnson, B.; Chen, W.; Wong, M. W.; Andres, J. L.; Gonzalez, C.; Head-Gordon, M.; Regpole, E. S.; Pople, J. A. Gaussian 98, Revision A.9. Gaussian, Inc.: Pittsburgh, PA, 1998.

30. Dougherty, D.; Younathan, E. S.; Voll, R.; Abdulnur, S.; McGlynn, S. P. Photoelectron-Spectroscopy of Some Biological Molecules. J. Electron Spectrosc. Relat. Phenom. 1978, 13, 379 393.

31. Karbach, V.; Knochenmuss, R. Do Single Matrix Molecules Generate Primary Ions in Ultraviolet Matrix-Assisted Laser Desorption/Ionization. Rapid Commun. Mass Spectrom. 1998, 12, 968-974.

32. Lide, D. R. Handbook of Chemistry and Physics; 71st ed. CRC Press: Boca Raton, 1991.

33. Zenobi, R.; Knochenmuss, R. Ion Formation in MALDI Mass Spectromtry. Mass Spectrom. Rev. 1998, 17, 337-366.

34. Gianelli, L.; Amendola, V.; Fabbrizzi, L.; Pallavicini, P.; Mellerio, G. G. Investigation of Reduction of $\mathrm{Cu}$ (II) Complexes in Positive-Ion Mode Electrospray Mass Spectrometry. Rapid Commun. Mass Spectrom. 2001, 15, 2347-2353.

35. Williams, D.; Findeis, A. F.; Naylor, S.; Gibson, B. Aspects of the Production of FAB and SIMS Mass Spectra. J. Am. Chem. Soc. 1987, 109, 1980-1986.

36. Pelzer, G.; De Pauw, E.; Dung, D. V.; Marien, J. OxidationReduction Processes Occurring in Secondary Ion Mass Spectrometry and Fast Bombardment of Glycerol Solutions. J. Phys. Chem. 1984, 88, 5065-5068.

37. Martínez-Díaz, M. V.; Torres, T. Liquid Matrix Induced Processes in Fast Atom Bombardment Mass Spectrometry of Polyazacrown Transition Metal Complexes. Inorg. Chim. Acta 1994, 219, 85-92. 